\title{
Do Brands Matter in Unlisted Firms? An Empirical Study of the Association between Brand Equity and Financial Performance
}

\author{
Anne Schmitz * and Nieves Villaseñor-Román \\ Marketing Department, Autonomous University of Madrid, 28049 Madrid, Spain; nieves.villasenor@uam.es \\ * Correspondence: anne.schmitz@uam.es
}

Received: 5 September 2018; Accepted: 20 October 2018; Published: 25 October 2018

check for updates

\begin{abstract}
In spite of the importance of the brand management in marketing studies and practice, there is a scarcity of prior research on the links between brand equity and financial performance, particularly in unlisted (unquoted) firms. The study contributes to prior research along a number of dimensions. It provides evidence on the relevance of brands for unlisted firms of several industries, by showing that brand equity is associated with financial performance even in non-quoted firms without world-recognized brands. Second, the study analyzes the association between brands and accounting-based measures of performance, across different windows and financial indicators. Finally, the evidence on earnings persistence is particularly relevant, as it potentially sheds light on the existing debate on the association between brand equity and stock markets. To the extent that firms with greater brand equity have more persistent earnings, current earnings contain greater information about future earnings, which show the relevance of brand management in the strategic planning of unlisted firms.
\end{abstract}

Keywords: brand equity; financial performance; unlisted firms; earnings

\section{Introduction}

Brands differentiate firms from the competition. The conceptualizations of consumer-based brand equity have mainly derived from cognitive psychology and information economics (Rahman et al. 2018). The dominant stream of research has been grounded in cognitive psychology, focusing on memory structure (Christodoulides and De Chernatony 2010). Aaker (1991) identified the conceptual dimensions of brand equity as brand awareness, brand associations, perceived quality, brand loyalty, and other proprietary brand assets such as patents, trademarks and channel relationships. The former four dimensions of brand equity represent consumer perceptions and reactions to the brand, while proprietary brand assets are not pertinent to consumer-based brand equity. Keller (1993) defined the consumer-based brand equity as 'the differential effect of brand knowledge on consumer response to the marketing of the brand' and brand knowledge is a key antecedent of customer based brand equity. It is in turn conceptualized as a brand node in memory to which a variety of associations have been linked. Brand knowledge is then decomposed into two separate constructs: brand awareness and brand image (associations).

From the perspective of cognitive psychology, the customer based brand equity occurs when consumers hold some favorable, strong, and unique brand associations in memory, which in turn leads to incremental utility or valued added. Thus, investing in brand equity is expected to lead to differential consumer response that may positively affect firm value (through greater consumer retention, price tolerance, or word-of-mouth recommendations, for example).

While Aaker's brand equity model has been more frequently adopted in existing research, particularly empirical studies (Yoo and Donthu 2001), two research gaps remain unexplored in his 
model. First, the interrelationships between the four brand components are not considered. Second, Aaker's model does not integrate the effectiveness of marketing programs into the consumer-based brand equity concept (Keller and Lehmann 2006). In his customer-based brand equity definition, Keller highlights the importance of marketing programs in linking consumers' awareness, desired thoughts, feelings, perceptions, and opinions to a brand (Huang and Cai 2015). In addition, while Aaker's model places the four dimensions at the same level, Keller's customer-based customer equity stated that consumers' knowledge of a brand including awareness and perceptions will result in their attitudes and behaviors favorable to that brand. Keller argued that customer-based customer equity can largely be captured by four blocks that form a hierarchy pyramid, which are from the bottom (the lowest level) to the top (the highest level) as follows: brand identity, brand meaning, brand responses and brand relationships (Keller 2002).

Despite this appealing theoretical notion, a number of recent studies have tested the links between brand equity (and its components) and firm value, failing to provide a unifying body of evidence on this issue (Madden et al. 2006; Rego et al. 2009; Johansson et al. 2012; Larkin 2013; Narteh 2018; Kim et al. 2018). ${ }^{1}$

As noted in Ittner et al. (2009), a potential weakness of this prior work is that it hinges crucially on the often untested assumption that brand equity leads to enhanced firm performance, and thus much is still not known about the short- and long-window consequences of enhanced brand equity. Furthermore, Johansson et al. (2012) find that the strength of the relationship between brand equity and financial performance differs according to the measure applied and how each captures the equity. ${ }^{2}$ Indeed, there is a scarcity of prior research on the links between brand equity and financial performance, particularly in unlisted firms, even though there is some preliminary research focused on small and medium-sized enterprises (Anees-ur-Rehman et al. 2018).

This lack of evidence is potentially explained because prior literature on brand equity and the determinants of performance indicators have developed separately, with the possible exception of a limited number of accounting-based studies. This prior research in accounting attempts to clarify whether brand names are economic assets and should therefore be recognized in the balance sheet, ${ }^{3}$ that is, whether they are associated with firm performance. In this paper, we build on this prior research in accounting that suggests that brands are intangible assets that influence a firm's value and results (e.g., Barth et al. 1998) and study the association between brand equity and financial performance. As noted above, understanding how precisely brand equity impacts on firm performance is particularly relevant for unlisted firms. These firms represent a unique challenge because of data availability issues, but also a perfect setting for a test of brand equity and firm performance.

Tests conducted on unlisted firms do not suffer from the confounding effects that are pervasive in market-based research, particularly when studying intangible assets, such as brand equity (Ohlson 1998; Ittner et al. 2009). Our setting thus allows us to provide new evidence that permits understanding the interrelationships between brand equity and financial indicators. This is a key to better distributing marketing efforts towards the construction of a brand equity that serves to optimize firm profitability. In addition, by focusing on unlisted firms we can explore brand equity in firms that do not have worldwide recognized brands (such as those surveyed by Interbrand, Brand Z, or Brand Asset Valuator and generally analyzed in prior research).

If investment in brand equity leads to greater consumer retention, inelasticity to price increases, and lower volatility of sales, it is expected that it will lead to greater firm profitability, and greater

1 In particular, the study of the links between customer satisfaction and stock market pricing has attracted much controversy, providing mixed views and conflicting evidence (see, e.g., Aksoy et al. 2008; Ittner et al. 2009; Jacobson and Mizik 2009; Tuli and Bharadwaj 2009).

2 The authors work with listed companies and two brand equity proprietary metrics models, Interbrand and EquiTrend.

3 By definition, this implies that brand equity is associated with earnings. An asset is a resource controlled by the entity as a result of past events and from which future economic benefits are expected to flow (IASB International Accounting Standards Board). 
earnings persistence. We study if this is the case by looking at the association between brand equity and financial performance for a sample of Spanish unlisted firms.

Brand equity is measured from perspectives of Aaker (1991) and Keller (1993), both models have elements in common but are different in the building of customer-based customer equity. In our main tests, we use the models of Ittner and Larcker (1998) and Ittner et al. (2009) to study the association between financial performance as measured by a number of accounting-based measures and brand equity. This study represents progress in the research on the positive effects of brand equity in the strategic planning and financial performance of unlisted firms.

The remainder of the paper is structured as follows. The next section reviews the literature and presents our predictions. Another section details the methods and presents the results. Finally, the last section concludes.

\section{Literature Review and Hypotheses Development}

The debate on whether marketing investments constitute intangible assets and how to value them has been present in the accounting literature for decades (e.g., Abdel-Khalik 1975; Hirschey and Weygandt 1985) and in the marketing literature more recently (e.g., Madden et al. 2006; Rego et al. 2009; Johansson et al. 2012). In the last few years, in the multidisciplinary literature calls for greater emphasis on the reporting and disclosure of non-financial measures, such as on customer satisfaction, have been motivated by the widespread perception that marketing efforts are key drivers of firm value (Srinivasan and Hanssens 2009; Livne et al. 2011).

In particular, recent research emphasizes the importance of brand equity. The concept of brand equity has its origins in cognitive psychology (Aaker 1991, 1996; Keller 1993, 2002) as a measure of the long-term results achieved by the investment made in the creation and strengthening of brands. Brand equity represents the consumers' perceptions and attitudes towards it. As noted in Campo et al. (2013), perceptions are, in turn, a function both of organic sources, such as word-of-mouth recommendations, and of induced sources, like the brand positioning created by the firm and its marketing communication. Prior literature indicates that brand equity is a good measure of the effectiveness of brand investments. In particular, Keller (2003) interprets brand equity as a bridge between the marketing efforts dedicated in the past to the creation of a brand and their future results.

Although definitions of brands differ, the underlying notion is that a brand is a distinctive name with which consumers have a high level of awareness and a willingness to pay either higher than otherwise average prices or make higher than otherwise purchase frequency. Some of the benefits of a brand name would be: greater loyalty, less vulnerability to competitive marketing actions and economic crises, larger margins, less (more) elastic response to price increases (decreases), greater trade cooperation and support, increased marketing communication effectiveness, or greater supply chain power.

As argued in Barth et al. (1998), the net effect of all these positive consequences would be that brand equity provides a firm with a higher level of operating earnings over time (relative to otherwise unbranded firms). However, not all expenses incurred in promoting a brand result in brand equity. Advertising efforts can misfire with dire consequences, and it is less obvious what the benefits of brand equity are in smaller, unlisted firms, which do not have world-renowned brands, bringing into question how brand equity increases operating performance and value for these firms.

Recent research in marketing has started to address related issues, by studying the links between marketing and firm value (Srinivasan and Hanssens 2009), and more specifically, between brand equity and stock performance. For example, brand equity has been introduced as a mediator between different marketing variables (corporate social responsibility) and financial performance (Malik and Kanwal 2018). However, despite some evidence on the positive effect of brand equity on a firm's market performance and risk (Madden et al. 2006; Rego et al. 2009), these prior studies generally provide mixed results and inconclusive evidence on the links between brand equity and financial measures. Although the studies that indicate a positive association between brand equity 
and stock returns or profit efficiency are important for understanding the link between branding and shareholder value, they do not unequivocally demonstrate how precisely branding affects performance directly, thereby leading to positive market consequences. Furthermore, results also show considerable heterogeneity across industries (Mizik and Pavlov 2017).

We expect that brand equity improves financial performance by increasing the loyalty of existing customers, reducing price elasticities, lowering marketing costs thorough positive word-of-mouth, enhancing firm reputation and lowering transaction costs. Thus, we expect that brand equity leads to greater consumer satisfaction, engagement and loyalty, and thus, to smoother, more predictable streams of earnings. While not directly looking at brand equity, but studying the influence of marketing efforts on profitability, prior research by Krasnikov et al. (2009) is consistent with the view that marketing efforts can affect profitability. These authors show that firms that deploy consumer relationship management have greater profit efficiency.

Given the above discussion, we test the following hypothesis:

Hypothesis 1 (H1). Brand equity is positively associated with firm financial performance in unlisted firms.

This hypothesis is tested using two different indicators of customer-based customer equity. The first indicator based on the four dimensions of Aaker (1991) and the second indicator based on the approach of Keller (1993). This is to establish whether the relationship between customer-based customer equity and financial performance is independent or not of the indicators used to measure brand equity.

\section{Methods and Data}

We study the association between brand equity and firm performance, and also whether firms that invest more in brand equity benefit from smoother earnings streams, by looking at earnings persistence. In this section, we first describe our proxy of brand equity, then we explain the models used to test our hypotheses.

\subsection{Measuring Brand Equity}

There are two proxies used to measure customer-based customer equity. Both are measured with a set of items from a survey of marketing managers of Spanish service firms. The items come from previously validated scales. All items are measured using a Likert scale of 11 points from 0 (totally disagree) to 10 (totally agree). Specifically, the items are: awareness (in its market, its brands are well known); image (among their clients, their brand image is very good); perceived quality (among their customers, the perceived quality of their brand is very good); and loyalty (their customers are very loyal to their brand).

The first proxy is a variable that derives from the scale of Aaker (1991), which is calculated as an average score of items that reflect the four components of the concept: awareness, image, perceived quality, and loyalty. The second proxy is based on the model of Keller (1993), which is calculated as an average score of items that reflect the two main components of the knowledge concept: awareness and image.

\subsection{Association between Brand Equity, Firm Performance and Earnings Persistence}

We predict that firms that invest in brand equity will benefit from better performance. Prior work by Johansson et al. (2012) provides evidence consistent with this claim, although their evidence is indirect and focuses only on quoted firms. To ascertain the association between brand equity and firm performance, we run the following simple model, based on the work of Ittner and Larcker (1998) and Ittner et al. (2009):

$$
\text { Perfomance }=\alpha+\beta \text { Brand Equity }+\delta \text { Controls }+\varepsilon
$$


where, Performance is a proxy of firm performance, defined as accounting return-on-assets measured as the decile rank of earnings before interest and tax expenses scales by lagged assets. It is also calculated a proxy of Aaker's brand equity and a proxy of Keller's brand equity. In sensitivity analyses we also use as indicators of brand equity its individual components as well as an average score of quality and loyalty. Finally, controls is a vector of control variables derived from Ittner and Larcker (1998) and Ittner et al. (2009) that may affect financial performance. In particular, in our first specification, we control for firm size, measured as the natural logarithm of total assets; age, measured as the number of years since the firm was first incorporated; and leverage as the ratio of total liabilities to total assets.

If brand equity is positively associated with enhanced firm performance, we expect that $\beta$ will be significantly positive in model (1), indicating that those firms that invest more in brand equity have greater performance as measured by firm profitability.

\subsection{Sample Selection and Data}

To conduct our analysis we base our work on a sample of Spanish unquoted service firms that responded to a questionnaire on brand equity. Our brand equity proxies come from this questionnaire, which is described in detail in the section above. The $95 \%$ of firms of the sample declare that their corporate brand contributes to improve the firm value but only the $39.8 \%$ of firms measure some components of the customer-based customer equity and the $36 \%$ of firms affirm to assess the economic or monetary value of their corporate brand.

Accounting data comes from Orbis. The sample consisted of 201 firms, including companies with more than 50 employees (see Table 1).

Table 1. Population and sample.

\begin{tabular}{|c|c|c|c|c|c|c|}
\hline Industries & $\begin{array}{l}\text { Number of } \\
\text { Companies }\end{array}$ & $\begin{array}{c}\% \text { of } \\
\text { Companies }\end{array}$ & $\begin{array}{c}\text { Average Operating } \\
\text { Incomes } \\
\text { (Thousands of } \\
\text { Euros Per Year) }\end{array}$ & $\begin{array}{l}\text { Average } \\
\text { Number of } \\
\text { Employees }\end{array}$ & $\begin{array}{l}\text { Number of } \\
\text { Companies in } \\
\text { the Sample }\end{array}$ & $\begin{array}{c}\text { Percentage of } \\
\text { Companies in } \\
\text { the Sample }\end{array}$ \\
\hline $\begin{array}{l}\text { Accommodation and } \\
\text { food service activities }\end{array}$ & 1166 & 20.30 & $11,709.95$ & 198 & 61 & 30.35 \\
\hline $\begin{array}{l}\text { Administrative and } \\
\text { support service } \\
\text { activities }\end{array}$ & 513 & 8.93 & $40,707.47$ & 498 & 14 & 6.97 \\
\hline $\begin{array}{l}\text { Arts, entertainment } \\
\text { and recreation }\end{array}$ & 104 & 1.81 & $15,906.07$ & 141 & 4 & 1.99 \\
\hline Education & 175 & 3.05 & 7442.72 & 132 & 9 & 4.48 \\
\hline $\begin{array}{c}\text { Financial and } \\
\text { insurance activities }\end{array}$ & 181 & 3.15 & $106,268.56$ & 187 & 5 & 2.49 \\
\hline Real estate activities & 73 & 1.27 & $56,323.79$ & 130 & 3 & 1.49 \\
\hline $\begin{array}{l}\text { Retail trade, except of } \\
\text { motor vehicles } \\
\text { and motorcycles }\end{array}$ & 214 & 3.72 & $296,873.21$ & 1470 & 8 & 3.98 \\
\hline $\begin{array}{l}\text { Supplies, sewerage, } \\
\text { waste management and } \\
\text { remediation activities }\end{array}$ & 210 & 3.66 & $149,430.98$ & 367 & 4 & 1.99 \\
\hline $\begin{array}{l}\text { Transportation and } \\
\text { storage }\end{array}$ & 1049 & 18.26 & $48,112.45$ & 309 & 31 & 15.42 \\
\hline
\end{tabular}

For this sample, we collect all financial data. We require the availability of at least three years of consecutive data to calculate earnings persistence measures (from $t-2$ to $t$ ). This results in a final sample of 182 firms, and 1338 firm-year observations, albeit sample sizes change slightly in some of our tests. 
Table 2 provides descriptive statistics of the main variables of interest. We provide descriptive statistics for both the separate elements and two average scores; Aaker's brand equity and Keller's brand equity. We also present evidence on an average score of brand equity, which aggregate perceived quality and loyalty. Table 2 also contains descriptive evidence on the financial proxies of interest and controls. The sample is composed of healthy firms. The mean firm is profitable, with a mean (median) ROA of 0.04 (0.04), has low leverage and an age of 19 years. The evidence reported in Table 2 indicates that there are a number of extreme values in the distribution of ROA and validates the use of a decile rank measure to assess financial performance.

Table 2. Descriptive evidence.

\begin{tabular}{ccccccccc}
\hline & Obs. & Min. & Quartile1 & Mean & Median & Std. & Quartile3 & Max. \\
\hline Awareness & 1338 & 2.0 & 6.0 & 7.4 & 8.0 & 1.7 & 8.0 & 10 \\
Image & 1338 & 4.0 & 7.0 & 7.8 & 8.0 & 1.3 & 9.0 \\
Quality & 1338 & 5.0 & 7.0 & 7.9 & 8.0 & 1.1 & 9.0 \\
Loyalty & 1338 & 3.0 & 6.0 & 7.3 & 7.0 & 1.4 & 8.0 & 10 \\
A's BE & 1338 & 4.5 & 6.8 & 7.6 & 7.5 & 1.1 & 8.5 \\
Keller's BE & 1338 & 3.5 & 6.5 & 7.6 & 7.5 & 1.3 & 8.5 & 10 \\
Q+L quaEQ_QL & 1338 & 5.0 & 7.0 & 7.6 & 7.5 & 1.1 & 8.5 \\
IC & 1338 & 0.0 & 3.3 & 4.7 & 4.7 & 1.9 & 6.0 & 10 \\
ROA & 1237 & -1.68 & 0.00 & 0.04 & 0.04 & 0.15 & 0.08 & 0.3 \\
ROA & 1237 & -1.27 & 0.00 & 0.05 & 0.04 & 0.14 & 0.09 & 0.66 \\
P & 1237 & 1.00 & 3.00 & 5.01 & 5.00 & 2.77 & 7.00 & 10.00 \\
Age & 1237 & 1 & 10 & 19 & 17 & 16 & 24 \\
Size & 1237 & 0.10 & 8.26 & 9.10 & 9.06 & 1.30 & 9.83 \\
Leverage & 1237 & 0.00 & 0.01 & 0.17 & 0.09 & 0.21 & 0.27 \\
\hline
\end{tabular}

Notes: BE: Brand Equity. Q+L: Brand Equity as average of quality and loyalty. IC: Composite measure of industry competition. The composite measure of industry competition is obtained from the survey. ROA is earnings before interest and tax expenses scaled by lagged assets. A's BE: Aaker's brand equity. P: Perform is a decile rank transformation of ROA. Age is the number of years since the firm was incorporated. Size is the natural logarithm of firm total sales. Leverage is the ratio of firm total liabilities to total assets. Obs.: Observations. Min.: Minimum. Std.: Standard Deviation. Max.: Maximum.

Table 3 contains the correlation matrix. As expected, all components of brand equity are positively associated with firm performance, with all correlations being statistically significant. Also, as expected, there are high correlations between the individual components of brand equity and between the individual components and the aggregate measure (Aaker's brand equity). The strongest individual correlation is between quality and perform (correlation $=0.150, p$-value $<0.01$ ). ROA is highly correlated to lagged ROA, indicating a high persistence of financial performance, consistent with the arguments in Ittner et al. (2009). All other correlations are as expected, and below 0.05 . Indeed, the highest one is between age and size (correlation $=0.324, p$-value $<0.01$ ), which is as expected, as with age, firms tend to grown larger.

Table 3. Correlation matrix.

\begin{tabular}{|c|c|c|c|c|c|c|c|c|c|c|}
\hline & $\mathbf{P}$ & A & I & $\mathbf{Q}$ & $\mathbf{L}$ & $A^{\prime}$ 's BE & IC & $\mathbf{P}_{-1}$ & Age & Size \\
\hline Awareness & $\begin{array}{c}0.079 \\
0.01\end{array}$ & & & & & & & & & \\
\hline Image & $\begin{array}{c}0.101 \\
0.00\end{array}$ & $\begin{array}{c}0.624 \\
0.00\end{array}$ & & & & & & & & \\
\hline Quality & $\begin{array}{c}0.150 \\
0.00\end{array}$ & $\begin{array}{c}0.531 \\
0.00\end{array}$ & $\begin{array}{c}0.729 \\
0.00\end{array}$ & & & & & & & \\
\hline Loyalty & $\begin{array}{c}0.096 \\
0.00\end{array}$ & $\begin{array}{c}0.547 \\
0.00\end{array}$ & $\begin{array}{c}0.580 \\
0.00\end{array}$ & $\begin{array}{c}0.496 \\
0.00\end{array}$ & & & & & & \\
\hline Aaker's BE & $\begin{array}{c}0.124 \\
0.00\end{array}$ & $\begin{array}{c}0.843 \\
0.00\end{array}$ & $\begin{array}{c}0.874 \\
0.00\end{array}$ & $\begin{array}{c}0.803 \\
0.00\end{array}$ & $\begin{array}{c}0.793 \\
0.00\end{array}$ & & & & & \\
\hline IC & $\begin{array}{c}0.119 \\
0.00\end{array}$ & $\begin{array}{c}0.017 \\
0.54\end{array}$ & $\begin{array}{c}-0.045 \\
0.11\end{array}$ & $\begin{array}{c}0.081 \\
0.00\end{array}$ & $\begin{array}{c}0.105 \\
0.00\end{array}$ & $\begin{array}{c}0.045 \\
0.12\end{array}$ & & & & \\
\hline
\end{tabular}


Table 3. Cont

\begin{tabular}{ccccccccccc}
\hline & $\mathbf{P}$ & $\mathbf{A}$ & $\mathbf{I}$ & $\mathbf{Q}$ & $\mathbf{L}$ & $\mathbf{A}$ 's BE & IC & $\mathbf{P}_{-\mathbf{1}}$ & Age & Size \\
\hline ROA $_{\mathrm{t}-1}$ & 0.554 & 0.047 & 0.049 & 0.103 & 0.068 & 0.077 & 0.057 & & & \\
& 0.00 & 0.10 & 0.09 & 0.00 & 0.02 & 0.01 & 0.04 & & & \\
Age & -0.111 & 0.139 & 0.127 & 0.150 & 0.048 & 0.139 & 0.024 & -0.052 & & \\
& 0.00 & 0.00 & 0.00 & 0.00 & 0.09 & 0.00 & 0.40 & 0.07 & & \\
Size & 0.008 & 0.126 & 0.056 & 0.095 & 0.027 & 0.094 & 0.136 & 0.016 & 0.324 & \\
& 0.77 & 0.00 & 0.05 & 0.00 & 0.34 & 0.00 & 0.00 & 0.58 & 0.00 & \\
Leverage & -0.225 & -0.098 & -0.074 & -0.101 & -0.157 & -0.130 & -0.050 & -0.131 & 0.000 & -0.094 \\
& 0.00 & 0.00 & 0.01 & 0.00 & 0.00 & 0.00 & 0.08 & 0.00 & 0.99 & 0.00 \\
\hline
\end{tabular}

Notes: See Table 2 for variable definitions. P: Perform. A: Awareness. I: Image. Q: Quality. L: Loyalty. A's BE: Aaker's brand equity.

\section{Results}

\subsection{Association between Brand Equity and Financial Performance}

In our main tests, we regress performance on measures of brand equity and controls. Table 4 reports results of running model (1) using the individual components of brand equity first, and then, the aggregate scores. We run model (1) using data-panel techniques and clustering the standard errors both at the firm and year level, following Petersen (2009). This is the same method used in Ittner et al. (2009) to correct for both serial and cross-sectional dependence. Considering the brand equity components used, perceived quality is significant, which is consistent with the evidence reported in the correlation table (coefficient $=0.405, p$-value $<0.01$ for quality). Between the two aggregate scores, Aaker's brand equity presents highly significant results, while hardly any of Keller's brand equity reaches an acceptable level of significance. Herein, we conduct all analyzes with the scale of Aaker's brand equity model.

Table 4. Relation between brand equity (and components) and performance.

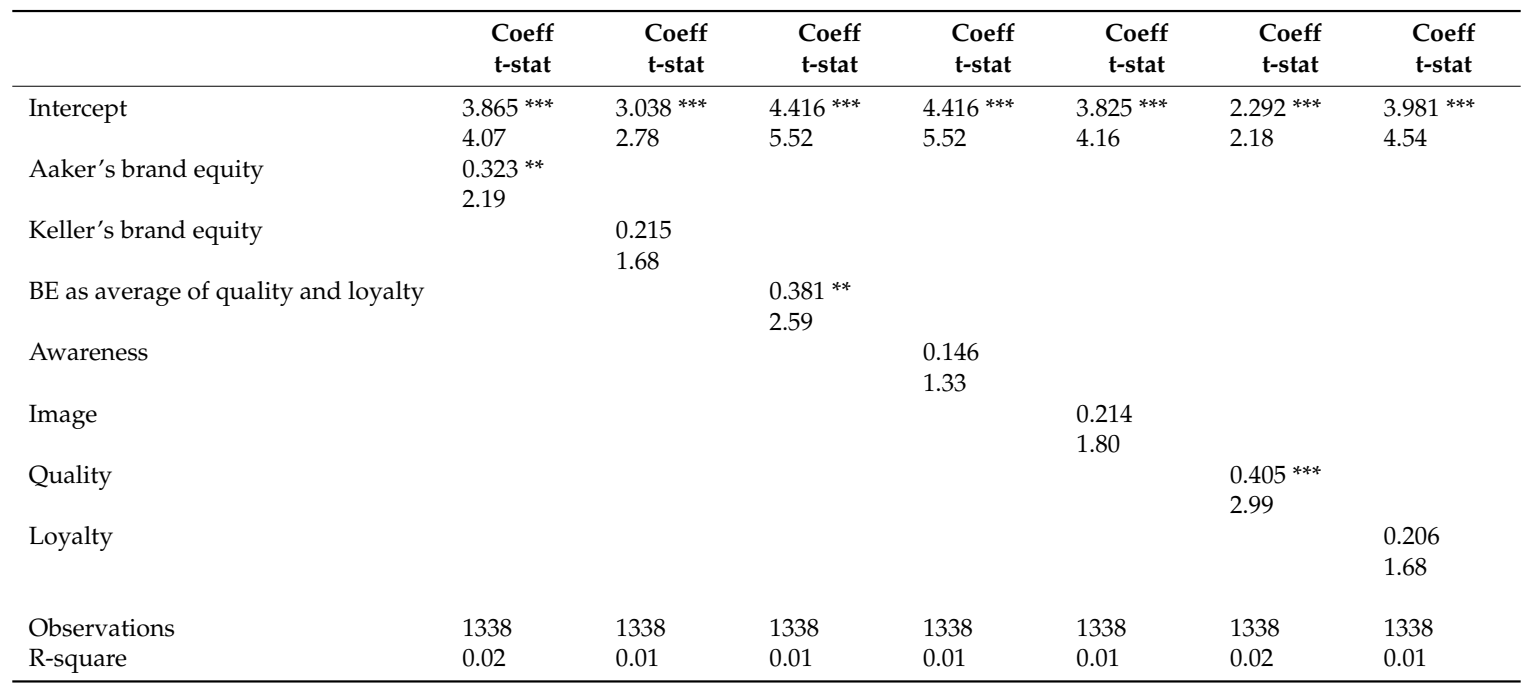

Notes: Coeff. t-stat: $\mathrm{t}$-statistic coefficient. BE: brand equity. ${ }^{* *}$, and ${ }^{* *}$ indicate coefficients are significant at the $1 \%$ and $5 \%$

Table 5 presents results from our main tests. The evidence is presented in four columns. The first column incorporates industry competition as an additional control, the second column contains the full model, as based on Ittner and Larcker (1998), where we also incorporate age, size and leverage as controls for firm performance. Finally, we run two additional variations of the model, including lagged performance and industry dummies. As before, all standard errors are clustered at the firm and year level. Our main variable of interest is Aaker's brand equity. If firms that have greater brand equity have superior financial performance, we predict Aaker's brand equity to be significantly positive. 
The results from Table 4 Panel B confirm this intuition. Aaker's brand equity is consistently positive and significant across all model specifications. The last two specifications contain lagged performance as a control. As predicted, the coefficient on this variable is positive and significant, confirming the importance of controlling for prior year performance, and consistent with prior research that indicates that performance is very persistent (see, e.g., Penman 1992). In the last specification, where we include industry dummies, R-square rises to 0.404 , indicating an adequate fit of the model. Also note that, in this model, industry competition is no longer significant, validating its use as a control for differences across industries. Overall, the results reported in Panels A and B of Table 4 strongly indicate a positive association between brand equity and financial performance, as measured by firm return on assets.

Table 5. Brand equity and performance, and controls.

\begin{tabular}{|c|c|c|c|c|}
\hline & $\begin{array}{c}\text { Coeff } \\
\text { t-stat }\end{array}$ & $\begin{array}{l}\text { Coeff } \\
\text { t-stat }\end{array}$ & $\begin{array}{c}\text { Coeff } \\
\text { t-stat }\end{array}$ & $\begin{array}{l}\text { Coeff } \\
\text { t-stat }\end{array}$ \\
\hline Intercept & $\begin{array}{c}2.381^{* *} \\
2.22\end{array}$ & $\begin{array}{c}3.401 \text { ** } \\
2.32\end{array}$ & $\begin{array}{c}3.587^{* * * *} \\
3.22\end{array}$ & $\begin{array}{c}2.865^{* * *} \\
2.95\end{array}$ \\
\hline Aaker's brand equity & $\begin{array}{c}0.298^{* *} \\
2.11\end{array}$ & $\begin{array}{c}0.276^{* *} \\
2.00\end{array}$ & $\begin{array}{c}0.186^{* *} \\
1.96\end{array}$ & $\begin{array}{c}0.192^{* *} \\
2.08\end{array}$ \\
\hline Industry competition & $\begin{array}{c}0.169 * * \\
2.39\end{array}$ & $\begin{array}{c}0.157^{* *} \\
2.19\end{array}$ & $\begin{array}{c}0.119 \text { ** } \\
2.47\end{array}$ & $\begin{array}{c}0.030 \\
0.58\end{array}$ \\
\hline Age & & $\begin{array}{c}-0.024^{* *} \\
-2.52\end{array}$ & $\begin{array}{c}-0.017^{* *} \\
-2.42\end{array}$ & $\begin{array}{c}-0.008 \\
-1.17\end{array}$ \\
\hline Size & & $\begin{array}{c}0.015 \\
0.11\end{array}$ & $\begin{array}{c}0.010 \\
0.10\end{array}$ & $\begin{array}{c}-0.001 \\
-0.01\end{array}$ \\
\hline Leverage & & $\begin{array}{c}-2.812^{* * *} \\
-4.46\end{array}$ & $\begin{array}{c}-2.010 * * * \\
-3.86\end{array}$ & $\begin{array}{c}-1.321^{* * * *} \\
-2.93\end{array}$ \\
\hline $\mathrm{ROA}_{\mathrm{t}-1}$ & & & $\begin{array}{c}10.28^{* * *} \\
6.88\end{array}$ & $\begin{array}{c}9.63^{* * * *} \\
7.88\end{array}$ \\
\hline Industry dummies & & & & Included \\
\hline Observations & 1237 & 1237 & 1237 & 1237 \\
\hline R-square & 0.03 & 0.09 & 0.35 & 0.40 \\
\hline
\end{tabular}

Notes: ${ }^{* * *}$, and ${ }^{* *}$ indicate coefficients are significant at the $1 \%$ and $5 \%$ or better levels, using a two-tail test. See Table 1 for variable definitions. Coeff. t-stat.: t-statistic coefficient.

\subsection{Sensitivity Analyses}

To check the robustness of our findings, we conduct a number of sensitivity analyses. First of all, we repeat our main analyses focusing on an alternative performance indicator: earnings persistence. Finally, we use alternative definitions of performance. In this section, we explain each of these robustness checks in turn.

\subsection{Analysis of Earnings Persistence}

To further understand how brand equity affects financial performance, we look at the association between brand equity and earnings persistence. As argued in Frankel and Litov (2009), understanding the factors that drive earnings persistence is of practical importance, since such knowledge is key for earnings prediction and thus, for equity valuation. To test whether brand equity is one such factor, we modify the simple method described in Frankel and Litov (2009) and Dichev and Tang (2009) and regress current earnings on 1-year lagged earnings and brand equity, as follows:

$$
\begin{gathered}
\text { Performancet }=\alpha+\beta 1 R^{R O A}+1+\beta 2 \text { Aaker's brand equity }+\beta 3 \mathrm{ROA}_{\mathrm{t}-1} * \\
\text { Aaker's brand equity }+\varepsilon t
\end{gathered}
$$

where ROA is defined as earnings before interest and tax expenses deflated by lagged total assets and Aaker's brand equity has already been defined. The coefficient of interest in model (2) is $\beta 3$ which captures the incremental persistence of earnings in firms that invest in brand equity. This coefficient is expected to be significantly positive, indicating that firms that invest in brand 
equity have more persistent earnings streams. Given our prior prediction, we expect $\beta 2$ will be also positive, indicating that, overall, greater investment in brand equity is associated with greater firm performance. As additional specifications, we add control variables to model (2) following prior research, and consistent with model (1) above. The results from this analysis are reported in Table 6.

Table 6. Sensitivity analyses. Brand equity and persistence of performance.

\begin{tabular}{cccc}
\hline & $\begin{array}{c}\text { Coeff } \\
\text { t-stat }\end{array}$ & $\begin{array}{c}\text { Coeff } \\
\text { t-stat }\end{array}$ & $\begin{array}{c}\text { Coeff } \\
\text { t-stat }\end{array}$ \\
\hline Intercept & $4.583^{* * *}$ & $4.670^{* * *}$ & $4.042^{* * *}$ \\
& 4.85 & 3.64 & 3.67 \\
Aaker's brand equity & 0.032 & 0.029 & 0.012 \\
& 0.26 & 0.24 & 0.10 \\
ROA $_{\text {t-1 }}$ & -13.219 & -11.291 & -11.442 \\
& -1.55 & -1.43 & 0.118 \\
Aaker's brand equity*ROA & $3.378^{* * *}$ & $3.035^{* * *}$ & $2.954^{* * *}$ \\
& 3.14 & 3.03 & 3.14 \\
Industry Competition & & $0.101^{* *}$ & 0.021 \\
& & 2.43 & 0.47 \\
Age & & $-0.015^{* *}$ & -0.007 \\
Size & & -2.28 & -1.04 \\
Leverage & & 0.014 & 0.01 \\
& & 0.14 & 0.15 \\
Industry dummies & & $-1.943^{* * *}$ & $-1.362^{* * *}$ \\
Observations & & -4.01 & -3.13 \\
R-square & 1237 & 1237 & 1237 \\
\hline
\end{tabular}

Note: ***, and ${ }^{* *}$ indicate coefficients are significant at the $1 \%$ and $5 \%$ or better levels.

We report three specifications, one with only the main variables of interest, one with controls, and a final one with industry dummies. As before, we use the panel data estimation technique, clustering the standard errors at the firm and year levels. Our main coefficient of interest is $\beta 3$ that captures the incremental persistence of earnings in firms that have greater brand equity. If brand equity leads to greater earnings persistence, this coefficient is expected to be significantly positive. The results from this test confirm that brand equity is positively associated with earnings persistence. The interaction is significantly positive across all three specifications (coefficient $=3.378, p$-value $<0.01$ in column 1 , coefficient $=3.035, p$-value $<0.01$ in column 2 , and coefficient $=2.954$, $p$-value $<0.01$ in column 3 ).

\subsection{Alternative Definition of Performance}

In our final sensitivity analysis, we repeat our main analyses using three alternative definitions of performance, the first one is future profitability (defined as before, but measured in $t+1$ ), and the second and third ones are measures of profitability incorporated after interest charges (profit before tax) and bottom line earnings (net income). Results from this test are reported on Table 7 and are consistent with our previous finding, confirming the positive association between brand equity and financial performance. 
Table 7. Sensitivity analyses. Alternative definitions of performance.

\begin{tabular}{cccc}
\hline & Perform1 & Perform2 & Perform3 \\
\cline { 2 - 4 } & $\begin{array}{c}\text { Coeff } \\
\text { t-stat }\end{array}$ & $\begin{array}{c}\text { Coeff } \\
\text { t-stat }\end{array}$ & $\begin{array}{c}\text { Coeff } \\
\text { t-stat }\end{array}$ \\
\hline Intercept & $3.494^{* * *}$ & $3.570^{* * *}$ & $4.067^{* * *}$ \\
& 3.51 & 4.15 & 4.55 \\
Aaker's brand equity & $0.227^{* *}$ & $0.185^{* *}$ & 0.158 \\
& 1.91 & 1.92 & 1.74 \\
Industry Competition & 0.030 & 0.045 & 0.037 \\
& 0.53 & 0.88 & 0.66 \\
Age & -0.010 & -0.011 & -0.014 \\
& -1.23 & -1.39 & -1.55 \\
Size & -0.049 & 0.031 & 0.036 \\
& -0.45 & 0.30 & 0.36 \\
Leverage & $-1.130^{* * *}$ & $-2.465 * * *$ & $-2.777 * * *$ \\
& -2.97 & -4.07 & -5.16 \\
ROA & $6.956^{* * *} 1$ & $7.802 * * *$ & $8.022^{* * *}$ \\
& 7.07 & 8.01 & 4.13 \\
Industry dummies & Included & Included & Included \\
Observations & 1081 & 1237 & 1236 \\
R-square & 0.33 & 0.44 & 0.40 \\
\hline
\end{tabular}

Notes: $* * *$, and ${ }^{* *}$ indicate coefficients are significant at the $1 \%$ and $5 \%$ or better levels, using a two-tail test. See Table 1 for variable definitions. Coeff. t-stat.: t-statistic coefficient.

\section{Discussion}

We study the association between brand equity and financial performance in unlisted (non-quoted) firms. This association has not been explored in detail in prior work, albeit some recent research indicates that a positive association exists between brand equity and measures of market value and performance of the listed firms and with global strong brands. Our results indicate that unlisted firms that invest more in brand equity have stronger financial performance, more earnings persistence and greater future profitability. This is consistent with brand equity serving to create value for firms and with the importance of brand equity in the strategic planning of unlisted firms.

We show that brand equity is strongly and positively associated with financial performance, both over long and short windows. The positive relationship between brand equity and financial performance is stronger and more significant when measured with the model of Aaker (1991) than when modeled of Keller (1993). Our results indicate that, considering the four components of brand equity, it is quality that shows the strongest association with financial performance. These results are robust to the inclusion of a number of additional control variables and alternative definitions of financial performance. We also show that firms with greater equity show greater earnings persistence, as measured using models consistent with Frankel and Litov (2009) and Dichev and Tang (2009).

Our study contributes to prior research along a number of dimensions. First, it provides evidence on the relevance of brands for unlisted firms, by showing that brand equity is associated with financial performance even in firms that are not quoted and do not have world-recognized brands. Moreover, this association is stronger when the brand equity component of perceived quality is included. In particular, we find that the quality component is mainly related to these positive economic consequences. Second, we contribute to the literature that links brand equity and firm value, by providing evidence on the association between brands and accounting-based measures of performance, across different windows and financial indicators. Finally, the evidence on earnings persistence is particularly relevant, as it potentially sheds light on the existing debate on the association between brand equity and stock markets. To the extent that firms with greater brand equity have more persistent earnings, current earnings contain greater information about future earnings, thus potentially leading to stronger association between brand measures and market returns. In addition, the results add to the growing literature in accounting on the determinants of earnings volatility and earnings predictability. This is relevant as a number of prior studies hinge on the prediction of earnings. Valuation research 
typically uses projections of earnings to derive estimates of firm and equity value. These studies are concerned with understanding what firm characteristics may help in the projection of future fundamentals and, particularly, of future earnings (Dichev and Tang 2009). Analysts and other market participants are continuously looking for information that may help them more accurately predict earnings. The results reported in this paper would suggest that brands are a key component of this information.

Author Contributions: A.S. wrote part of the paper and N.V.-R. has participated in the design of the research. All authors read and approved the final manuscript.

Funding: Financial support of the project ECO2015-69103-R.

Acknowledgments: The authors acknowledge the contribution of Beatriz García-Osma in relation to the data analysis and the research design.

Conflicts of Interest: The authors declare no conflict of interest.

\section{References}

Aaker, David A. 1991. Managing Brand Equity. New York: The Free Press.

Aaker, David A. 1996. Building Strong Brands. New York: The Free Press.

Abdel-Khalik, A. Rashad. 1975. Advertising effectiveness and accounting policy. The Accounting Review 50: 657-70.

Aksoy, Lerzan, Bruce Cooil, Christopher Groening, and Timothy L. Keiningham. 2008. The long-term stock market valuation of customer satisfaction. Journal of Marketing 72: 105-22. [CrossRef]

Anees-ur-Rehman, Muhammad, Ho Yin Wong, Parves Sultan, and Bill Merrilees. 2018. How brand-oriented strategy affects the financial performance of B2B SMEs. Journal of Business $\mathcal{E}$ Industrial Marketing 33: 303-15.

Barth, Mary E., Michael B. Clement, George Foster, and Ron Kasznik. 1998. Brand values and capital market valuation. Review of Accounting Studies 3: 41-68. [CrossRef]

Campo, Sara, Alejandro Gómez, and María Jesús Yagüe. 2013. The Impact of Destination Brand Personality on Destination Brand Equity. Madrid: Autónoma University Madrid.

Christodoulides, George, and Leslie De Chernatony. 2010. Consumer-based brand equity conceptualization and measurement. International Journal of Market Research 52: 43-66.

Dichev, Ilia D., and Vicki Wei Tang. 2009. Earnings volatility and earnings predictability. Journal of Accounting and Economics 47: 160-81. [CrossRef]

Frankel, Richard, and Lubomir Litov. 2009. Earnings persistence. Journal of Accounting and Economics 47: 182-90. [CrossRef]

Hirschey, Mark, and Jerry J. Weygandt. 1985. Amortization policy for advertising and research and development expenditures. Journal of Accounting Research 23: 326-35. [CrossRef]

Huang, Zhuowei Joy, and Liping A. Cai. 2015. Modeling consumer-based brand equity for multinational hotel brands-When hosts become guests. Tourism Management 46: 431-43. [CrossRef]

IASB (International Accounting Standards Board). 2010. Conceptual Framework for Financial Reporting. London: IASB.

Ittner, Christopher D., and David F. Larcker. 1998. Are nonfinancial measures leading indicators of financial performance? An analysis of customer satisfaction. Journal of Accounting Research 36: 1-34. [CrossRef]

Ittner, Christopher, David Larcker, and Daniel Taylor. 2009. The stock market's pricing of customer satisfaction. Marketing Science 25: 826-35. [CrossRef]

Jacobson, Robert, and Natalie Mizik. 2009. The financial markets and customer satisfaction: Reexaming possible financial market mispricing of customer satisfaction. Marketing Science 28: 810-19. [CrossRef]

Johansson, Johny K., Claudiu V. Dimofte, and Sanal K. Mazvancheryl. 2012. The performance of global brands in the 2008 financial crisis: A test of two brand value measures. International Journal of Research in Marketing 29: 235-45. [CrossRef]

Keller, Kevin Lane. 1993. Conceptualizing, measuring, and managing customer-based brand equity. Journal of Marketing 57: 1-22. [CrossRef]

Keller, Kevin Lane. 2002. Building Customer-Based Brand Equity: A Blueprint for Creating Strong Brands. Cambridge: Marketing Science Institute. 
Keller, Kevin Lane. 2002. Building, Measuring, and Managing Brand Equity, 2nd ed. Upper Saddle River: Prentice Hall.

Keller, Kevin Lane. 2003. Strategic Brand Management. Upper Saddle River: Prentice-Hall.

Keller, Kevin Lane, and Donald R. Lehmann. 2006. Brands and branding: Research findings and future priorities. Marketing Science 25: 740-59. [CrossRef]

Kim, Renee B., Jong Min Park, and Dong Hyun Yoon. 2018. Marketing Accountability of Korea Corporate: The Relationship between Branding Investments and Financial Performance. Engineering Economics 29: 332-40. [CrossRef]

Krasnikov, Alexander, Satish Jayachandran, and V. Kumar. 2009. The impact of customer relationship management implementation on cost and profit efficiencies: Evidence from the U.S. commercial banking industry. Journal of Marketing 73: 61-76. [CrossRef]

Larkin, Yelena. 2013. Brand perception, cash flow stability, and financial policy. Journal of Financial Economics 110: 232-53. [CrossRef]

Livne, Gilad, Ana Simpson, and Eli Talmor. 2011. Do Customer Acquisition Cost, Retention and Usage Matter to Firm Performance and Valuation? Journal of Business Finance \& Accounting 38: 334-63.

Madden, Thomas J., Frank Fehle, and Susan Fournier. 2006. Brands matter: An empirical demonstration of the creation of shareholder value through branding. Journal of the Academy of Marketing Science 34: 224-335. [CrossRef]

Malik, Muhammad Shoukat, and Lubna Kanwal. 2018. Impact of Corporate Social Responsibility Disclosure on Financial Performance: Case Study of Listed Pharmaceutical Firms of Pakistan. Journal of Business Ethics 150: 69-78. [CrossRef]

Mizik, Natalie, and Eugene Pavlov. 2017. Assessing the Financial Impact of Brand Equity with Short Time-Series Data. In Handbook of Market Research. Edited by Christian Homburg, Martin Klarmann and Arnd Vomberg. Cham: Springer.

Narteh, Bedman. 2018. Brand equity and financial performance: The moderating role of brand likeability. Marketing Intelligence \& Planning 36: 381-95.

Ohlson, James A. 1998. Discussion of "Brand values and capital market valuation". Review of Accounting Studies 3: 69-71. [CrossRef]

Penman, Stephen H. 1992. Return to fundamentals. Journal of Accounting, Auditing and Finance 7: 465-83. [CrossRef]

Petersen, M. A. 2009. Estimating standard errors in finance panel data sets: Comparing approaches. The Review of Financial Studies 22: 435-80. [CrossRef]

Rahman, Mahabubur, M. Ángeles Rodríguez-Serrano, and Mary Lambkin. 2018. Brand management efficiency and firm value: An integrated resource based and signalling theory perspective. Industrial Marketing Management 72: 112-26. [CrossRef]

Rego, Lopo L., Matthew T. Billett, and Neil A. Morgan. 2009. Consumer-based brand equity and firm risk. Journal of Marketing 73: 47-60. [CrossRef]

Srinivasan, Shuba, and Dominique M. Hanssens. 2009. Marketing and firm value: Metrics, methods, findings, and future directions. Journal of Marketing Research 66: 293-312. [CrossRef]

Tuli, Kapil R., and Sundar G. Bharadwaj. 2009. Customer satisfaction and stock returns risk. Journal of Marketing 73: 184-97. [CrossRef]

Yoo, Boonghee, and Naveen Donthu. 2001. Developing and validating a multidimensional consumer-based brand equity scale. Journal of Business Research 52: 1-14. [CrossRef]

(C) 2018 by the authors. Licensee MDPI, Basel, Switzerland. This article is an open access article distributed under the terms and conditions of the Creative Commons Attribution (CC BY) license (http://creativecommons.org/licenses/by/4.0/). 